\title{
Lactose hydrolysis by free and fibre-entrapped $\beta$-galactosidase from Streptococcus thermophilus
}

\author{
ZhenNaI YANG, Eero PAHKAla and TuOMo TUPASEla
}

\begin{abstract}
Y Ang, Z., PAhkala, E. \& Tupasel. A, T. 1993. Lactose hydrolysis by free and fibre-entrapped-galactosidase from Streptococcus thermophilus. Agric. Sci. Finl. 2: 395-401. (Jilin Academy of Agric. Sci., Branch of Animal Husbandry, Lab of Animal Products Processing, Gong-Zhu-Ling, Jilin Province, 136100 P.R. China and Agric. Res. Centre of Finland, Food Res. Inst., FIN-31600 Jokioinen, Finland.)
\end{abstract}

\begin{abstract}
To study lactose hydrolysis by $\beta$-galactosidase, this enzyme was produced from Streptococcus thermophilus strain $11 \mathrm{~F}$ and partially purified by acetone and ammonium sulphate fractionation, and ion exchange chromatography on a Q Sepharose FF column. Lactose hydrolysis by the enzyme was affected by lactose concentrations, sugars and milk proteins. The maximum extent of lactose hydrolysis in buffer was obtained with a $15 \%$ lactose concentration. Addition of $2 \%$ of lactose, glucose, galactose or sucrose in milk inhibited the enzymatic hydrolysis. The enzyme was activated by bovine serum albumin and a combination of $\alpha$ s-casein and $\beta$-casein. Of the casein fractions, the principal fraction, $\alpha$ s-casein, was less effective than $\beta$-casein and $\kappa$-casein. The fibreentrapped enzyme had a temperature optimum of $57^{\circ} \mathrm{C}$, and a pH optimum from 7.5 to at least 9.0 with $\mathrm{O}$-nitrophenyl- $\beta$-D-galactopyranoside as substrate. By recycling with whey and skim milk through a jacketed glass column $(1.6 \mathrm{~cm} \times 30 \mathrm{~cm})$ loaded with fibre-entrapped enzyme at $55^{\circ} \mathrm{C}$, a lactose hydrolysis of $49.5 \%$ and $47.9 \%$ was achieved in $11 \mathrm{~h}$ and $7 \mathrm{~h}$ respectively.
\end{abstract}

Key words: lactose hydrolysis, Streptococcus thermophilus, $\beta$-galactosidase, fibre-entrapped enzyme

\section{Introduction}

Hydrolysis of lactose in milk and milk products by $\beta$-galactosidase has been regarded as a potential solution to lactose maldigestion, which occurs in the majority of adults all over the world. Manufacture of dairy products with lactose-hydrolyzed milk or whey has many advantages, including enhanced sweetness, improved carbohydrate solubility and digestibility, more readily fermentable sugars, prevention of lactose crystallization etc. Enzymatic processes of lactose hydrolysis by both free and immobilised $\beta$-galactosidase are already commer- cially available (MAHONEY 1985, HARJU 1987). The utilization of $\beta$-galactosidase available from yeast and mould, however, is relatively limited, either due to the low temperature optimum or the low $\mathrm{pH}$ optimum of the enzyme. Attention has recently been shifted to finding a heat-stable, neutral-pH $\beta$-galactosidase that would be suitable for the hydrolysis of lactose in milk and facilitate the enzyme reactors with high operating temperatures to prevent microbial contamination. A thermostable $\beta$-galactosidase from Streptococcus thermophilus (Str. thermophilus) is considered such an enzyme and appears promising in this respect. The 
purification and characterization of the enzyme has been the subject of several recent studies (RAMANA and DutTA 1981, GREENBERG and MAHONEY 1982, GREENBERG et al. 1985, SMART et al. 1985, CHANG and MAHONEY 1989a, b). However, the research on the immobilization of the enzyme is still lacking and certain factors influencing the enzymatic hydrolysis of lactose need to be determined in more detail.

The present study was carried out to assay the hydrolysis of lactose in milk and buffer by the $\beta$-galactosidase from Str. thermophilus, and to evaluate the enzyme immobilized with cellulose triacetate.

\section{Material and methods}

Str. thermophilus strain 11F was donated by the Research and Development Centre of Valio Ltd., Helsinki. Cellulose triacetate was purchased from Fluka Chemie AG, Switzerland, O- nitrophenyl- $\beta$ D-galactopyranoside (ONPG) from Sigma Chemical Company, USA, and Q Sepharose FF and the glass column were from Pharmacia Fine Chemicals, Sweden. The chemicals and reagents used were of analytical grade. Double-distilled water was used to make the buffers. Raw milk and whey from edam cheese manufacture were obtained from the dairy of the Food Research Institute, Jokioinen, Finland.

\section{Enzyme preparation}

The procedures of bacterial cultivation and enzyme purification by acetone and ammonium sulphate precipitation basically followed an earlier method described by CHANG and MAHONEY (1989a).

The enzyme extract obtained was further partially purified by ion exchange chromatography with Q Sepharose FF in a glass column $(1.6 \mathrm{~cm} \times 30$ $\mathrm{cm})$. The elution was carried out at $5 \mathrm{ml} / \mathrm{min}$ with a linear increasing gradient of $0.5 \mathrm{M} \mathrm{NaCl}$ in buffer A (CHANG and MAHONEY 1989a) from 30\% to $80 \%$. The fractions $(10 \mathrm{ml})$ containing enzyme activity were pooled, the protein was precipitated by adding ammonium sulphate to $65 \%$ saturation, and the pellet was dissolved in about $10 \mathrm{ml}$ buffer $\mathrm{A}$ and dialyzed at $4^{\circ} \mathrm{C}$ against buffer $\mathrm{A}$ with several changes of the buffer. The enzyme was stored at $-25^{\circ} \mathrm{C}$. The above procedures of enzyme preparation were carried out and repeated five times. The final enzyme products were used for the following assays of lactose hydrolysis and enzyme immobilization.

\section{Assay of $\beta$-galactosidase activity and protein concentration}

Enzymatic activity was spectrophotometrically measured at $420 \mathrm{~nm}$ as described by GREENBERG et al. (1985). One unit of $\beta$-galactosidase activity is defined as the amount of enzyme which will liberate $1 \mu \mathrm{mol}$ of o-nitrophenol (ONP) per minute under the assay conditions.

Protein concentration was determined by the method described by LOWRY et al. (1951). Bovine serum albumin was used as standard protein.

\section{Immobilization of the enzyme}

The partially purified enzyme preparations were entrapped in cellulose triacetate fibres (thickness $0.2-0.3 \mathrm{~mm}$ ) according to the procedures reported by MORISI et al. (1973).

\section{Determination of the optimum temperature and pH of the fibre-entrapped enzyme}

The activity of the fibre-entrapped enzyme during the assays was examined as follows: $0.15 \mathrm{~g}$ fibres were added to $2 \mathrm{ml} 2.2 \mathrm{mM}$ ONPG in buffer at $55^{\circ} \mathrm{C}$ in a water bath. The absorbance of the solution at $420 \mathrm{~nm}$ was measured after 2 minutes. The $\mathrm{pH}$ optimum was determined with $2 \mathrm{ml} 2.2 \mathrm{mM}$ ONPG in $0.01 \mathrm{M}$ potassium phosphate buffer adjusted to the $\mathrm{pH}$ of the assay with phosphoric acid. The temperature optimum was determined with $2 \mathrm{ml} 2.2 \mathrm{mM}$ ONPG in buffer A at the assay temperatures. 


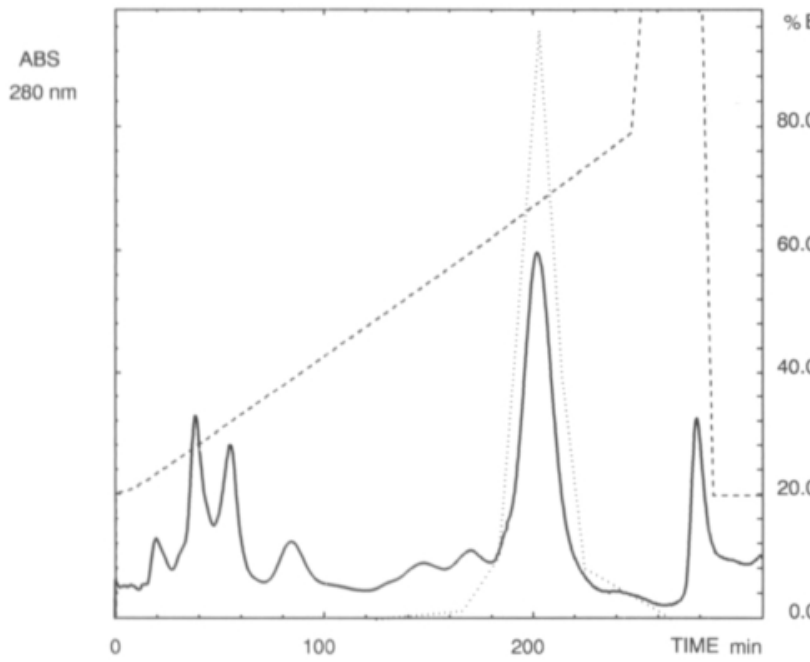

2

Fig. 1. Purification of the enzyme by ion exchange chromatography on a $\mathrm{Q}$ Sepharose FF column. (- absorbance, (---) $\mathrm{NaCl}$ gradient, (...) enzyme activity

\section{Assay of lactose hydrolysis}

Lactose hydroiysis was assayed with a rapid method based on the measurement of freezing point depressing of the solution as described by RAMET et al. (1979). $2 \mathrm{ml}$ of sample (or diluted sample) was taken, and the freezing point determined with a cryoscope.

\section{Results and discussion}

\section{Enzyme purification}

Elution of the enzyme extract by ion exchange chromatography on a Q Sepharose FF column is shown in Figure 1. The dialysate from the ammonium sulphate step had to be centrifuged because of its thickness, and only the supernatant (about 58\% of the total activity) was applied to the column. The precipitate, with a specific activity of 16 units/mg protein, could be directly freeze-dried as a crude enzyme. Elution of the enzyme started shortly after the specified gradient was introduced. One main peak of protein coincident with the enzyme activity was eluted. The pooled fractions from the main peak, however, accounted for $86 \%$ of the total activity recovered, with a four-fold increase in spe- cific activity compared with the applied enzyme sample. Thus, further purification of the enzyme was not carried out. The final partially purified enzyme had a specific activity of 117 units/mg protein.

\section{Lactose hydrolysis in milk and buffer containing carbohydrates or milk proteins}

\section{Effect of lactose concentrations}

As shown in Figure 2, the process of lactose hydrolysis by the enzyme was examined at different concentrations of lactose in $0.025 \mathrm{M}$ potassium phosphate buffer, $\mathrm{pH} 6.8$, containing $0.8 \mathrm{mM}$ $\mathrm{MgCI} 2.6 \mathrm{H} 2 \mathrm{O}, 0.125 \mathrm{mM}$ dithioerythritol, $0.005 \%$ NaN3 and 10\% glycerol (buffer B).

Maximum hydrolysis was found in a $15 \%$ lactose solution, in which $100 \%$ of lactose was hydrolyzed in 4 hours. With lactose concentrations of 5\%, 10\% and $25 \%$, the degrees of hydrolysis after 4 hours were about $70 \%, 85 \%$ and $50 \%$, respectively. Similar results were observed by using Saccharomyces fragilis lactase to hydrolyze reconstituted whey and milk, where the highest degree of lactose hydrolysis was achieved at $10-15 \%$ lactose concentrations (WENDORFF et al. 1971). It seems that optimal in- 


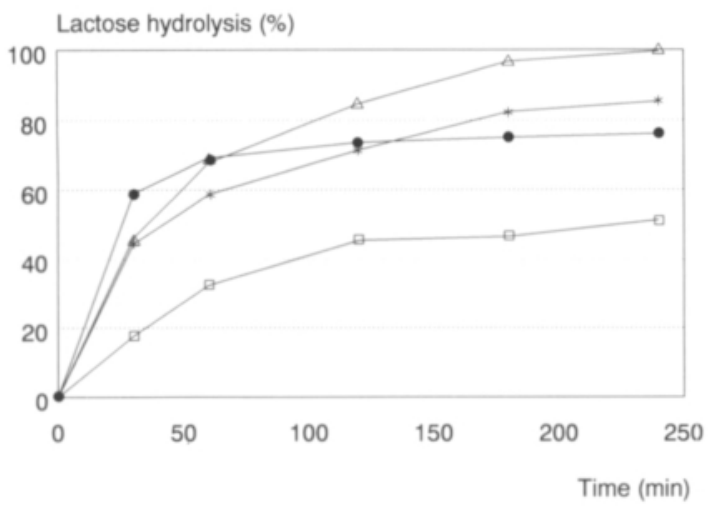

- $5 \%$ lactose $* 10 \%$ lactose $\triangle 15 \%$ lactose $\square 25 \%$ lactose

Fig. 2. Hydrolysis of lactose at $55^{\circ} \mathrm{C}$ in buffer B . $10 \mathrm{ONPG}$ units of enzyme activity were added per $\mathrm{ml}$ of buffer $\mathrm{B}$.

teraction between the enzyme and lactose occurres when lactose concentration was about $15 \%$.

\section{Effect of sugars}

Figure 3 shows that lactose hydrolysis was remarkably reduced when $2 \%$ of lactose, glucose, galactose or sucrose was added to the milk. Lactose gave the slightest inhibition to the hydrolysis, whereas there was no evident difference between inhibition caused by the other sugars.

The results in Figure 2 indicate that lactose hydrolysis increased along with increasing lactose concentration in buffer (except $25 \%$ ). Adding lactose to milk, however, decreased the lactose hydrolysis. Lactose, galactose and glucose have been found to stabilize $\beta$-galactosidase from Str. thermophilus (CHANG and MAHONEY 1989b), but the lactose hydrolysis in milk by the enzyme may be reversely affected by these sugars.

\section{Effect of milk proteins}

The effect of several casein fractions and bovine serum albumin on lactose hydrolysis in buffer B containing $15 \%$ lactose is shown in Figure 4. The concentrations of $\alpha$-casein, $\kappa$ - casein and $\beta$-casein in buffer B were similar to their corresponding concentrations in milk. After 3 hours, the hydroly-

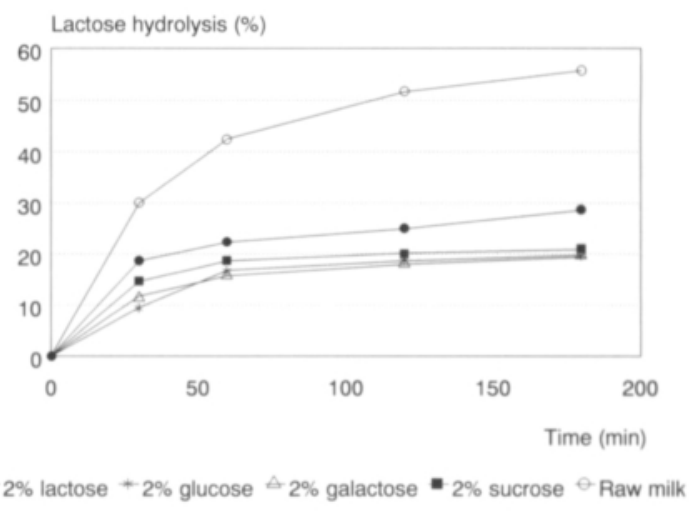

Fig. 3. Hydrolysis of lactose at $55^{\circ} \mathrm{C}$ in milk with added sugars . 8 ONPG units of enzyme activity were added per $\mathrm{ml}$ of milk.

sis degrees in buffer B containing $\alpha$ s-casein and $\beta$ casein, or bovine serum albumin, reached $95 \%$, almost the same as achieved in $15 \%$ lactose solution within the same time but using a higher enzyme concentration (shown in Figure 2). This suggests that the enzyme was activated by bovine serum albumin and by the combination of $\alpha$ s-casein and $\beta$-casein. Previous work (MAHONEY and ADAMCHUK 1980) has also shown that $\beta$-galactosidase from $S$. fragilis is strongly activated by bovine serum albumin. Casein has been found to activate $\beta$-galactosidase from $S$. fragilis and stabilize $\beta$-galactosidase from Str. thermophilus (CHANG and MAHONEY 1989b). However, the results in Figure 4 indicate that the individual effects of casein fractions on the enzyme were different. $\alpha$ s-casein was less effective than $\beta$-casein and $\kappa$-casein, although it is the principal fraction of casein. $\kappa$-casein, comprising only about $13 \%$ of the total casein, produced the greatest effect.

\section{Immobilization of the enzyme}

\section{pH optimum}

The results (Figure 5) indicate a wide $\mathrm{pH}$ optimum range from 7.5 to at least 9.0 with a sharp decrease of enzyme activity below $\mathrm{pH}$ 7.5. The optimum $\mathrm{pH}$ 


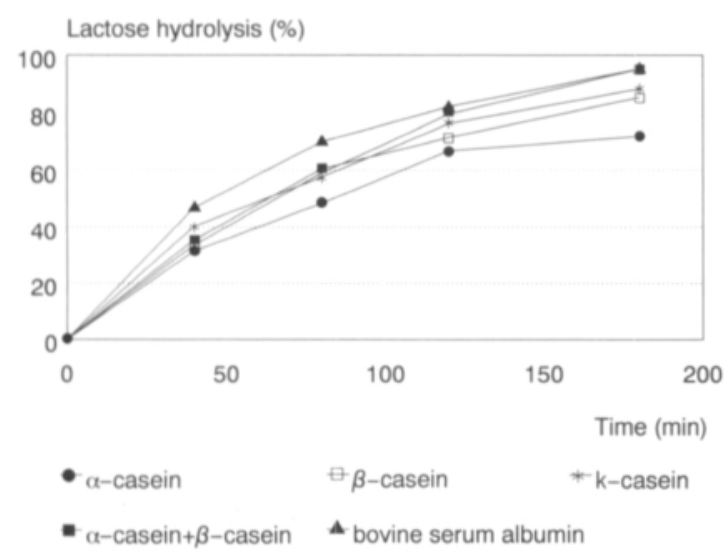

Fig. 4. Hydrolysis of lactose at $55^{\circ} \mathrm{C}$ in buffer $\mathrm{B}$ with added milk proteins . 7 ONPG units of enzyme activity were added per $\mathrm{ml}$ of buffer $\mathrm{B}$.

for this free enzyme has been reported to be between 7.0 and 7.5 (SMART et al. 1985). The broader $\mathrm{pH}$ optimum of the fibre-entrapped enzyme was probably due to the rate limiting of the substrate diffusion. In addition, since the enzyme preparation was not entirely pure, some protein impurities entrapped in the fibres could also have contributed to the broader $\mathrm{pH}$ optimum. MORISI et al. (1973) reported a similar wider range of $\mathrm{pH}$ optimum for $\beta$-galactosidase from Escherichia coli. Immobilized crude pepsin has also been found to have a wider $\mathrm{pH}$ optimum range than another more pure immobilized pepsin preparation (HUSTAD et al. 1973).

\section{Temperature optimum}

The effect of different temperatures on the activity of the fibre-entrapped enzyme is shown in Figure 6. Of the temperatures studied, the optimum appeared to be at about $57^{\circ} \mathrm{C}$. This was an upward shift of about $2^{\circ} \mathrm{C}$ compared with the corresponding free enzyme, for which the optimum temperature has been reported at $55^{\circ} \mathrm{C}$ (SMART et al. 1985). Although the enzyme was actually entrapped in soluble form within the microcavities of the fibres, it may be that the outer layer of the fibres provided heat protection for the entrapped enzyme, thus resulting in a higher temperature optimum.

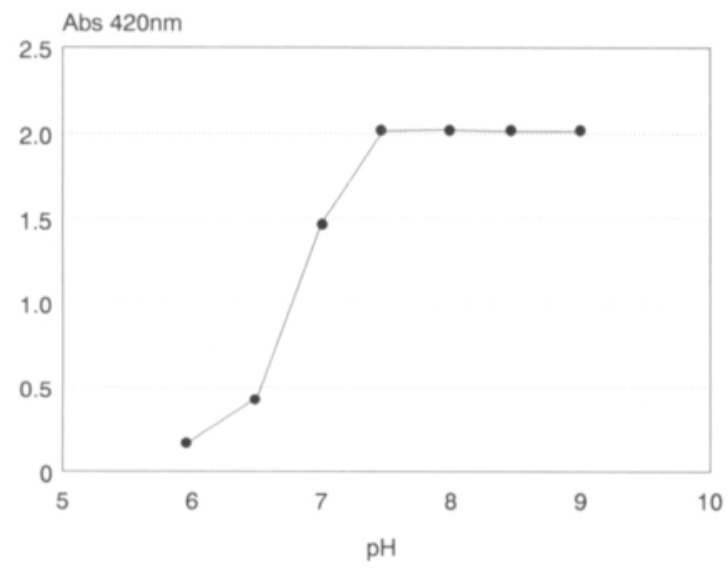

Fig. 5. pH profile of fibre-entrapped $\beta$-galactosidase with ONPG as substrate.

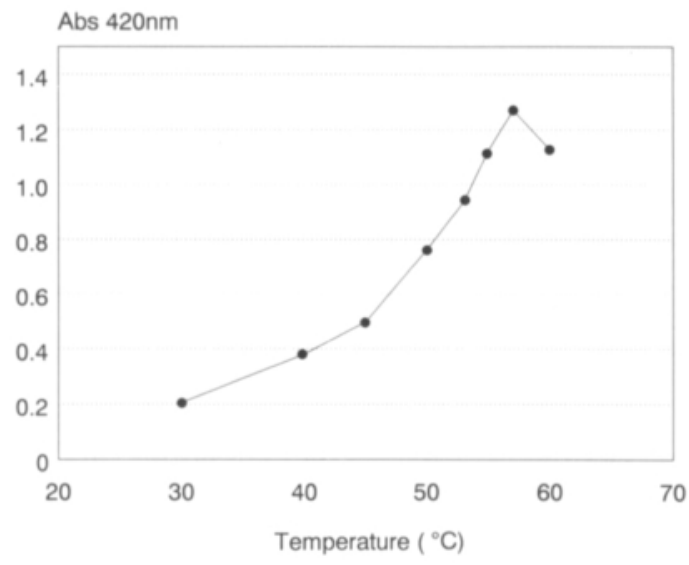

Fig. 6. Temperature profile of fibre-entrapped $\beta$-galactosidase with ONPG as substrate.

\section{Lactose hydrolysis in milk products by the fibre-entrapped enzyme}

Treating $15 \mathrm{ml}$ skim milk, whole milk or whey with $1.0 \mathrm{~g}$ of fibre-entrapped enzyme for 3 hours at $50^{\circ} \mathrm{C}$ or $53^{\circ} \mathrm{C}$ resulted in lactose hydrolysis of about $70 \%, 65 \%$ and $27 \%$, respectively (Figure 7 ). Skim milk and whole milk appeared to be more suitable than whey for lactose hydrolysis by the immobilized enzyme. The low extent of lactose hydrolysis in whey may be mainly due to the low $\mathrm{pH}$ of the 


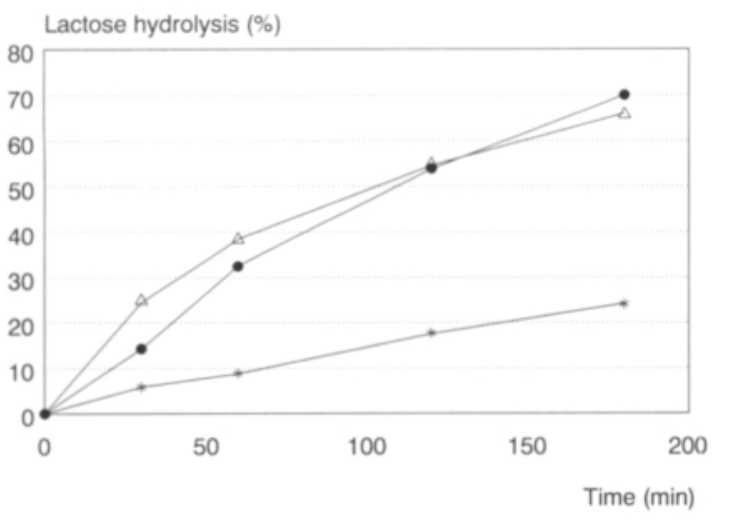

- Skim milk $\triangle$ Whole milk *Whey

Fig. 7. Lactose hydrolysis in milk products by fibre-entrapped $\beta$-galactosidase $\left(1.0 \mathrm{~g}\right.$ ) (skim milk $50^{\circ} \mathrm{C}$, whole milk $50^{\circ} \mathrm{C}$, whey $53^{\circ} \mathrm{C}$ ).

whey (about $\mathrm{pH}$ 6.3). As indicated in Figure 5, the activity of the immobilized enzyme was strongly affected by $\mathrm{pH}$ values below 7.5 .

\section{Column operation}

Trials were made to assay the performance of the enzyme entrapped in the fibres which were parallel- packed in the jacketed glass column (1.6 cm x 30 $\mathrm{cm})$. The first assay indicated that lactose hydrolysis of only $8.4 \%$ in whole milk was obtained with the column containing $9 \mathrm{~g}$ fibres at $45^{\circ} \mathrm{C}$ and at a flow rate of $38 \mathrm{ml} / \mathrm{h}$. The substrate was then changed by feeding whey at a lower flow rate, but no improvement was observed. The column was packed again using more fibres (13 g). After running with whey, skim milk and lactose solution in buffer $\mathrm{B}$ at above $50^{\circ} \mathrm{C}$ and at even lower flow rates, higher degrees of lactose hydrolysis were achieved, but they were still less than $30 \%$. When whole milk or skim milk was passed through the column at flow rates less than $20 \mathrm{ml} / \mathrm{h}$, column plugging by fat and protein became easier. The substrates were, therefore, recycled through the column at $55^{\circ} \mathrm{C}$ and at much higher flow rates (about $70 \mathrm{ml} / \mathrm{h}$ ), and lactose hydrolysis of $49.5 \%, 47.9 \%$ was reached with whey $(90 \mathrm{ml})$ and skim milk $(90 \mathrm{ml})$ after 11 and 7 hours respectively.

Acknowledgements. This work was initiated by the Agricultural Research Centre of Finland and JiLin Academy of Agricultural Sciences of P.R. China. The authors would like to thank the Finnish Ministry of Trade and Industry for financial support to this study.

\section{References}

Chang, B. \& Mahoney, R.R. 1989a. Purification and thermostability of $\beta$-galactosidase (lactase) from an autolytic strain of Streptococcus salivarius subsp. thermophilus. J. Dairy Res. 56: 117-127.

— \& Mahoney, R.R. 1989b. Factors affecting the thermostability of $\beta$-galactosidase (Streptococcus salivarius subsp. thermophilus) in milk: a quantitative study. J. Dairy Res. 56: 785-792.

Greenberg, N.A. \& Mahoney, R.R. 1982. Production and characterization of $\beta$-galactosidase from Streptococcus thermophilus. J. Food Sci. 47: 1824-1828, 1835.

-, WILDER, T. \& MahoneY, R.R. 1985. Studies on the thermostability of lactase (Streptococcus thermophilus) in milk and sweet whey. J. Dairy Res. 52: 439-449.

HarJu, M. 1987. Lactose Hydrolysis. IDF Bull. 212: 50-55.

Hustad, G.O., Richardson, T. \& Olson, N.F. 1973. Immobilization of $\beta$-galactosidase on an insoluble carrier with a polyisocyanate polymer. II. Kinetics and stability. J. Dairy Sci. 56: 1118-1122.

Lowry, O.H., Rosebrough, N.J., FarR, A.L. \& Randall,
R.J. 1951. Protein measurement with the folin phenol reagent. J. Biol. Chem. 193: 251-275.

MAHONEY, R.R. 1985. Modification of lactose and lactosecontaining dairy products with $\beta$-galactosidase. In: Fox P. (ed.). Developments in Dairy Chemistry-3. Elsevier Applied Science Publishers, London and New York. p. 69-109.

— \& Adамсник, C. 1980. Effect of milk constituents on the hydrolysis of lactose by lactase from Kluyveromyces fragilis. J. Food Sci. 45: 962-964, 968.

Morisi, F., PAstore, M. \& VigliA, A. 1973. Reduction of lactose content of milk by entrapped $\beta$-galactosidase. I. Characteristics of $\beta$-galactosidase from yeast and Escherichia coli. J. Dairy Sci. 56: 1123-1127.

Ramana Rao, M.V. \& Dutta, S.M. 1981. Purification and properties of $\beta$-galactosidase from Streptococcus thermophilus. J. Food Sci. 46: 1419-1423.

Ramet, J.P., NovaK, G., Evers, P.A. \& Nupels, H.N. 1979. Application de la cryométrie à la mesure de l'hydrolyse enzymatique du lactose. Le Lait 59: 46-55. 
Smart, J.B., Crow, V.L. \& Thomas, T.D. 1985. Lactose hydrolysis in milk and whey using $\beta$-galactosidase from Streptococcus thermophilus. New Zealand J. Dairy Sci. and Technol. 20: 43-56.

WendorfF, W.L., Amundson, C.H. \& Olson, N.F. 1971. Use of yeast $\beta$-galactosidase in milk and milk products. J. Milk Food Technol. 34: 294-299.
Manuscript received June 1993

Zhennai Yang

Jilin Academy of Agricultural Science

Branch of Animal Husbandry

Laboratory of Animal Products Processing

Gong-Zhu-Ling, Jilin Province

136100 P.R. China

Eero Pahkala

Tuomo Tupasela

Agricultural Research Centre of Finland

Food Research Institute

FIN-31600 Jokioinen, Finland

\title{
SELOSTUS
}

\section{Laktoosin hydrolyysi vapaalla ja kuituun sidotulla Streptococcus thermophilus- $\beta$-galaktosidaasilla}

\author{
Zhennai Yang, Eero PahKala ja TuOmo TuPASEla
}

Jilin Academy of Agricultural Sciences ja Maatalouden tutkimuskeskus

\begin{abstract}
Streptococcus thermophilus $11 \mathrm{~F}$ kannalla tuotettiin $\beta$-galaktosidaasia, joka osittain puhdistettiin asetoni- ja ammoniumsulfaattifraktioinnilla sekä ioninvaihtokromatografialla Q Sepharose FF-pylväässä. Entsyymin aiheuttamaan laktoosin pilkkoutumiseen vaikuttivat laktoosin pitoisuus, eri sokerit ja maidon valkuaisaineet. Korkein hydrolyysiaste puskuriliuoksessa saavutettiin $15 \%$ laktoosipitoisuudessa. Lisättäessä maitoon 2 \% joko laktoosia, glukoosia, galaktoosia tai sakkaroosia laktoosin hydrolyysi heikkeni. Seerumin albumiini
\end{abstract}

sekä $\alpha$ - ja $\beta$-kaseiinien yhdistelmä aktivoi entsyymiä. Maidon kaseiinien pääkomponentin, $\alpha$ s-kaseiinin vaikutus hydrolyysiin oli vähäisempi kuin $\beta$ - tai $\kappa$-kaseiinin. Kuituun sidotun entsyymin lämpötilaoptimi oli $57^{\circ} \mathrm{C}$ ja $\mathrm{pH}$ optimi välillä 7,5 9,0 käytettäessä O-nitrofenyyli- $\beta$-D-galactopyranosiidia subtraattina. Kierrätettäessä kuorittua maitoa tai heraa kuituun sidotulla entsyymillä täytetyssä lasikolonnissa saavutettiin $55^{\circ} \mathrm{C}$ lämpötilassa 7 tunnissa $47,9 \%$ ja 11 tunnissa $49,5 \%$ laktoosin hydrolyysiaste. 